\title{
Fenomena-Fenomena Paradigmatik Dunia Pengadilan di Indonesia (Telaah Kritis terhadap Putusan Sengketa Konsumen)
}

\author{
Artidjo Alkostar
}

\begin{abstract}
In issuing the court in Indonesia, the independence of the court is often interfered by power interest with many various background. Today, after the act No. 4, 2004 on the Judicial Affairs and the act No.5, 2004 on The Supreme Court issued, the effort of interference are probably not repeated. It is caused that judicature instifution both in organization, administration and financial are not directed by Department of Administration, but it applies the one roof policy under the Supreme Court. The significant change paradigmatically would strengthen the autonomy, transparence, and responsibility for every judge in deciding the case in the level of any judicature (Human Rights Judicature, Trade Judicature, Comuption Judicature and the Commission of Consumers Conflict Solution).
\end{abstract}

\section{Pengadilan sebagai Kontributor Pembangunan Peradaban}

Setiap bangsa atau kelompok masyarakat mempunyai kewajiban moral untuk menorehkan risalah peradabannya. Bangsa yang sanggup merasa mampu menuliskan risalah peradaban, telah dan akan menjadi saksi sejarah bagi eksistensi dan perjalanan umat manusia.hukum yang berlaku dalam suatu komunitas sosial atau bangsa, menjadi guru yang memberi pelajaran tentang interaksi antar insani dan sekaligus memberi arahan dinamika sosial bagi bangsa tersebut. Dalam hubungan ini menurut kacamata teori "Legal Process" bahwa judicial decision (putusan pengadilan) yang berpredikat reasoned elaboration' dituntut-untuk menghubungkan putusan dengan relevansi penegakan hukum. Lembaga pengadilan merupakan salah satu institusi yang menjalankan fungsi hukum atau menegakkan keadilan. Tidak ada bangsa yang dapat dikategorikan beradab tanpa mempunyai hukum yang adil dan pengadilan yang baik dan berdaulat.

'Feldman, Stephen M., American Legai Thought, From Premodemism to Postmodemism (New York: An Intelectual Voyage Oxford University Press, 2000), hlm. 121. 
Sejarah perjalanan umat manusia menunjukkan bahwa semakin baik hukum dan pengadilan suatu bangsa, akan semakin tinggi kualitas peradaban bangsa yang bersangkutan. Proses pengadilan yang transparan, logis, independen dan adil, telah dan akan memberikan kontribusi kebenaran moral dan pencerahan bagi pemikiran dan tingkah laku masyarakat secara elegan (anggun). Sebaliknya putusan pengadilan yang tidak nalar dan bertentangan dengan rasa keadilan masyarakat akan menimbulkan the dead of common sense atau matinya akal sehat. Putusan pengadilan memikul beban tanggung jawab agar menjadi figur puncak kearifan dari penyelesaian perkara yang terjadi di masyarakat. Putusan pengadilan yang benar dan penuh kearifan akan mencegah timbulnya sikap main hakim sendiri, ketidakpercayaan terhadap institusi pengadilan, sikap balas dendam dan sikapsikap berbarik (tidak beradab) lainnya.

Aturan hukum yang berupa undangundang tidak lepas dari proses politik dalam proses pembuatannya. Karakter perangkat hukum yang dilahirkan pada masa Orde Baru berwatak represif, feodalistik, dan berparadigma kekuasaan. Sedangkan dalam era reformasi, karakter produk hukumnya banyak mengadopsi hak-hak asasi manusia dan demokrasi. Paradigma hukum berkorelasi dengan hal-hal yang ada dalam metayuridis. Substansi hukum akan mempengaruhi dan membentuk karakter hukum yang berlaku dalam suatu negara. Hubungan korelasional di antara variabel-variabel tersebut di atas dapat dilihat juga dalam perspektif sistem hukum yang dikemukakan oleh Herbert Jacob ${ }^{2}$ yang menegaskan bahwa: the legal system in the United States reflects core values of the nation's political and legal tradition, particularly an emphasis on individual rights, a focus on the constitutionalism. Jadi pada dasarnya menurut Jacob sistem hukum di Amerika Serikat menunjukkan nilai dasar dari tradisi hukum dan politik bangsa, khususnya yang menyangkut hak-hak individu, suatu acuan atas konstitusionalisme, pemerintahan yang terbatas dan aspirasi egalitarianisme.

Permasalahan besar dalam dunia pengadilan di Indonesia sejak negara kita merdeka tahun 1945 adalah kebebasan pengadilan. Banyak pihäk yang ingin mempengaruhi, kekuasaan pengadilan dengan berbagai latar belakang kepentingan. Secara faktual yang sering mempengaruhi kebebasan pengadilan adalah kekuasaan politik, kekuasaan ekonomi, anggota masyarakat yang berperkara baik langsung maupun melalui penasehat hukumnya, atau bahkan dari elemen aparat penegak hukum sendiri. Secara yuridis, Pasal 4 ayat (4) UndangUndang No. 4 Tahun 2004 menentukan bahiwa perbuatan campur tangan terhadap proses peradilan diancam dengan pidana. Lebih dari itu, bisa juga aparat pengadilan entah itu panitera, hakim dan sebagainya memberi peluang untuk diintervensi. Ketidakbebasan pengadilan dapat menimbulkan praktek KKN (Korupsi, Kolusi, Nepotisme).

Negara Amerika Serikat memerlukan waktu 100 tahun (satu abad) untuk

2 Jacob, Herbert, Court, Law, and Politics in Comparative Perspective (New Haven: Yale University Press, 1996), hlm. 29. 
menempatkan pengadilan negara tersebut bebas dari pengaruh pemerintah (eksekutif) atau kekuasaan lain. Dalam hal ini Indonesia tidak memerlukan waktu 100 tahun, karena sejak tahun 2004 kekuasaan Kehakiman sepenuhnya berada di bawah kekuasaan Mahkamah Agung Rl. Dengan istilah lain indonesia telah menerapkan sistem satu atap (One Roof System). Dengan diundangkannya UU No. 4 Tahun 2004 tentang Kekuasaan Kehakiman dan UU No. 5 Tahun 2004 tentang Mahkamah Agung, terjadi perubahan paradigma dalam dunia peradilan di Indonesia. Para hakim pengadilan tingkat pertama dan tingkat banding, yang selama ini secara organisatoris, administratif, dan finansial berada di bawah departemen pemerintahan (kekuasaan eksekutif), diubah oleh Pasal 13 ayat (1) UU No. 4 Tahun 2004 pada posisi berada dalam kekuasaan Mahkamah Agung (yudikatif).

Lonjakan paradigmatik dalam perangkat hukum yang menyangkut peradilan juga muncul dalam format dilembagakannya dissenting opinion (pendapat hakim yang berbeda), yang wajib dimuat dan merupakan bagian yang tak terpisahkan dari putusan sebagaimana telah ditentukan dalam Pasal 19 ayat (4) dan (5) UU No. 4 Tahun 2004 jo Pasal 30 ayat (2) dan (3) UU No. 5 Tahun 2004. paradigma baru ini memberi penegasan tentang keharusan hukum adanya transparansi dan tanggung ajawab setiap hakim dalam memutus perkara.

Fenomena munculnya kelembagaan baru di dalam dunia pengadilan di Indonesia, antara lain dibentuknya Pengadilan HAM (Hak Asasi Manusia) berdasarkan UU No. 26 Tahun 2000 , yang dalam hal ini juga dibentuk Pengadilan HAM ad hoc, juga muncul Komisi Yudisial, Pengadilan Korupsi ad hoc, Pengadilan Niaga, Badan Penyelesaian Sengketa Konsumen, dan lain sejenisnya. Hal ini semua bertujuan membangun dunia pengadilan yang bermartabat dan berperan secara anggun (elegan) sebagai bagian dari pembangunan peradaban bangsa. Telaah tulisan ini membatasi pada keberadaan Badan Penyelesaian Sengketa Konsumen yang lahir berdasarkan UU No. 8 Tahun 1999.

\section{Kedudukan BPSK dalam Sistem \\ Pengadilan di Indonesia}

\section{Posisi BPSK dalam UU No. 8 Tahun 1999}

Postulat moral dikeluarkannya UndangUndang Nomor 8 Tahun 1999 antara lain adalah terciptanya Perekonomian yang sehat. Dalam proses pembangunan perekonomian nasioani pada saat yang sama para konsumen tidak dirugikan. Dalam hubungannya dengan perlindungan konsumen di Amerika Serikat dikenal adanya lembaga The Consumer Product Safetty Commission yang merupakan institusi pemerintah. ${ }^{3}$ Untuk itu diperlukan perangkat hukum yang memuat konstruksi hipotesis yang menjamin secara yuridis tentang perlindungan hukum bagi konsumen. Upaya untuk mecapai adanya tanggung jawab pelaku usaha serta kesadaran pengetahuan konsumen dalam melakukan hak dan

\footnotetext{
${ }^{3}$ Palast, Greg, The Best Democracy Money Can Buy (England: The Penguin Group, 2003), him. 227.
} 
kewajibannya.

UU No. 8 Tahun 1999 yang terdiri dari XV bab dan 65 Pasal menempatkan penyelesaian sengketa dalam bab $X$ yang memuat Pasal 45, 46, 47, dan 48. Sedangkan badan Penyelesaian Sengketa Konsumen (BPSK) diatur dalam Bab XI yang memuat Pasal 49 , $50,51,52,53,54,55,56,57$, dan 58. Badan Penyelesaian Sengketa Konsumen (BPSK) mempuinyai tugas dan wewenang pada intinya adalah: a. penanganan dan pernyelesaian melalui mediasi atau arbitrase atau konsiliasi: b. konsultasi; c. pengawasain; d. melaporan kepada penyidik; e menerima pengaduan; $f$. penelitian dan pemeriksaan; g. memanggil pelaku usaha; h menghadirkan saksi dan saksi ahli; i. Meminta bantuan penyidik untuk menghadirkan saksi; $j$. meneliti surat dokumen; k. menetapkan ada atau tidaknya kerugian konsumen; I. memberikan putusan; $m$. menjatuhkan sanksi administratif.

Dalam realitas sosial, antara konsumen dan pelaku usaha atau produsen, sering terjadi hubungan korelasional dan sebab akibat yang menyangkut hak dan kewajiban masingmasing pihak. Antara pelaku usaha atau produsen dengan konsumen atau pelanggan dapat terjadi hubungan saling membutuhkan. Dalam hubungannya dengan kepentingan pelanggan dan perusahaan, Kevin Kelly melukiskan bahwa: Costumer and company educated each other on what was possible. Good products and services are concreted: the desires of costumers grow out of what is possible, and what is posibble is made real by companies following new customer desires. ${ }^{4}$
Interaksi antara perusahaan dan pelanggan dapat saling mengisi dalam upaya mencapai pemenuhan hak dan kewajiban masingmasing secara harmonis. Dalam häl tindakan perusahaan yang dinilai merugikan pihak lain atau pemerintah di Amerika Serikat, Perusahaan Microsoft ${ }^{5}$ pernah digugat oleh Pemerintah Amerika Serikat tahun 19987, karena dituduh melakukan praktek monopoli.

\section{Penanganan dan Penyelesaian Sengketa oleh BPSK}

Secara limitatif metode penanganan dan penyelesaian sengketa konsumen oleh BPSK ditentukan oleh Mediasi, Arbitrase, atau Konsiliasi. Dalam hubungannya dengan Mediasi, Mahkamah Agung telah mengeluarkan PERMA No. 2 Tahun 2003 tentang Prosedur Mediasi di Pengadilan. Sedangkan mengenai Arbitrase secara yuridis diatur dalam UU No. 30 Tahun 1999 tentang Arbitrase dan Penyelesaian Sengketa. Dalam hal yang menyangkut Konsiliasi secara komparatif Joni Emirson mengemukakan bahwa Konsiliasi di AS merupakan tahap awal dari proses mediasi, dan tuntutan yang diajukan orang yang mengklaim (claimant) dapat diterimanya dalam kedudukannya sebagai responden. Dalam tahap yang demikian,telah diperoleh penyelesaian tanpa melanjutkan pembiayaan, karena pihak responden dengan kemauan baiknya (goodwill) bersedia menerima apa yang dikemukakan oleh claimant. Cara penyelesaian dengan goodwill demikian ini

"Kelly, Kevin, New Rules for The New Economy (New York: Penguin Group, 1998), hlm. 128.

${ }^{5}$ Mc. Kenzie, Richard, Trust on Trial (Cambridge: Percus Publishing, 2000), hlm. 223 
disebut konsiliasi winning over by goodwill .

Tujuan dikeluarkannya PERMA No. 2 Tahun 2003 adalah terwujudnya efektivitas, biaya murah adalah suatu speedy trial sehingga keberadaan pengadilan sesuai dengan hakikat keberadaannya dalam merealisasi keadilan bagi para pihak yang berperkara. Dalam upaya tersebut lembaga mediasi dijadikan faktor determinan, sehingga penerapannya menjadi wajib dalam proses mencapai perdamaian. Sifat wajib tersebut berlaku bagi para pihak yang berperkara agar melalui jalur mediasi dan bagi Hakim berwajitb untuk mengharuskan kepada para pihak serta menunda proses persidangan dalam rangka memberi kesempatan kepada pihak-pihak berperkara untuk menempuih proses mediasi.

Sesuai dengan dikeluarkannya PERMA No. 2 Tahun 2003 yang untuk mendukung asas pengadilan yang oleh lembaga dan biaya ringan, maka untuk memiliki sertifikat yang dikeluarkan oleh lembaga yang diakreditasi oleh Mahkamah Agung. Kecuali mediator itu dari Hakim yang pada dirinya telah memiliki kapasitas ilmu dan skill sehingga tidak diperlukan sertifikat bagi dirinya. Untuk itu sebelum ada orang yang memiliki sertifikat sebagai mediator, maka mediator itu harus diperankan oleh Hakim yang tersedia di Pengadilan Negeri yang bersangkutan. Sebagaimana dipaparkan oleh Max $\mathrm{H}$.
Bazeman dan Margareth A. Neale bahwa: mediators facilitate negotiation agreements by controling how the parties enteract. They can also help put together an agreement, but the parties decide whether to accept it. While mediation is a popular intervemtion strategy, it is not a panacea. ${ }^{6}$ Jadi menurut Bazerman dan Neale bahwa peran mediator itu menfasilitasi persetujuan dalam negosiasi dengan cara memantau bagaimana para pihak itu berinteraksi atau saling berkomunikasi pada hal-hal yang berhubungan dengan kasus hukum yang mereka hadapi. Mediator juga dapat membantu menuangkan pernyataan kesepakatan. Kendatipun mediasi merupakan strategi yang menyala dalam penyelesaian kasus perkara perdata, tetapi hal itu bukan merupakan suatu obat mujarab. Untuk itu diperlukan persyaratan tertentu' bagi orangorang yang akan menjadi mediator. Para mediator harus mampu menerjemahkan hak-hak yang melekat pada para pihak. Kemudian dengan posisi hukum yang dimiliki oleh para pihak serta didukung oleh alat-alat bukti yang ada, maka mediator dapat menjelaskan kepada masing-masing pihak secara faktual objektif.

Dengan memfungsikan mediator, maka proses ini mengacu pada model Self Help Legal System, dengan mediator yang ada dalam daftar yang dimiliki Pengadilan atau

- Bazeman, Max H., and Neale, Margareth A., Negotiation Rasionality (New York: The Free Press, 1993), hlm. 142. Lebih jauh bazeman dan Neale juga menegaskan bahwa: unfortunatel, mediation won't usually meet you ideal. Most mediators influence the dispute resolution process by not only fashioning agreements, but by convincing the parties to agree to them. For instance, in a negotiation between parties when one is clearly more powerful than the other, the mediator's goal of reaching an agreement makes possible three strategies. The mediator can thy to get both parties to make similar concessions, get the moer powerful party to concede, or get the weaker party to concede. 
mediator yang di luar daftar Pengadilan. Pemilihan mediator tersebut secara limitatif ditentukan paling lama satu hari kerja, sehingga para pihak atau kuasa hukumnya memiliki tanggung jawab untuk melaksanakan, karena diwajibkan (compulsory) secara yuridis. Selanjutnya apabila dalam jangka waktu satu hari para pihak atau kuasa hukumnya tidak mencapai kata sepakat tentang mediator (di dalam atau di luar daftar Pengadilan) maka para pihak diwajibkan menggunakan mediator yang tersedia dalam daftar Pengadilan. Selanjutnya Ketua Majelis Hakim dengan Penetapannya berwenang menunjuk seorang mediator, apabila dalam satu hari kerja para pihak tidak mencapai kata sepakat memilih seorang mediator dari yang disediakan Pengadilan:

Proses mediasi ditentukan paling lama 30 hari, setelah itu para pihak diwajibkan menghadap kembali persidangan yang telah ditentukan. Para pihak dapat meminta Penetapan Akta Perdamaian, apabila dalam proses mediasi tersebut dicapai adanya kesepakatan. Pihak Penggugat diwajibkan mencabut gugatannya meskipun mencapai kesepakatan tetapi tidak meminta Akta Perdamaian. Jadi secara yuridis produk hukum yang ditentukan oleh Pasal 5 ayat (3) PERMA No. 2 Tahun 2003 adalah penetapan dan bukan putusan. Hal ini merupakan konsekuensi dari adanya perangkat aturan tentang Pelaksanaan Tugas dan Administrasi Pengadilan dan perangkat hukum lainnya yang berkenan dengan Pengadilan dan Kekuasaan Kehakiman. Antara lain adalah yang dikenal dengan Buku 1. Dalam buku ini ditentukan antara lain dimungkinkannya keluar produk hukum berupa penetapan tentang Pelaksanaan Lelang, Sita Jaminan dan lain sejenisnya serta ditentukan pula institusi yang berwenang mengeluarkan penetapan misalnya Ketua Pengadilan, Ketua Majelis Hakim dan lain sebagainya.

Setelah Mediator dipilih atau ditunjuk, maka dalam tenggang waktu 7 hari (paling lama) para pihak wajib menyerahkan foto kopi dokumen yang memuat duduk perkara, foto kopi surat-surat yang diperlukan, dan hal-hal yang terkait dengan sengketa kepada Mediator dan Para Pihak (vide Pasal 8). Proses ini merupakan momentum untuk berunding secara jujur dalam upaya mencapai solusi terbaik berdasarkan posisi kasus dan fakta hukum masing-masing pihak. Dengan pertemuan yang terjadwal dan para pihak dapat didampingi kuasa hukum,mediator dapat melakukan kaukus, lalu Mediator memikul kewajiban mendorong para pihak untuk menelusuri dan menggali kepentingan mereka dan mencari berbagai pilihan penyelesaian yang terbaik bagi para pihak (Pasal 9). Proses mediasi dibatasi 22 hari (paling lama) dari sejak penetapan Mediator sampai tercapainya kesepakatan atau ketidaksepakatan. Penyediaan PERMA oleh Mahkamah Agung merupakan upaya MA (Mahkamah Agung) untuk memberi fasilitas hukum bagi masyarakat dalam memperoleh keadilan, termasuk masyarakat konsumen untuk mendapatkan keadilan seutuhnya atau total justice, termasuk hak mendapatkan kompensasi atau ganti kerugian dari pelaku usaha atau produsen. Hal ini tercakup dalam konsep yang diajukan oleh Lawrence Friedman bahwa: in all of these, one can see shadow of a major social norm, the norm of total justice - the general nation that catastrophes of all sorts "eam" compensation for the victims, so long as the victim was not evil 
enough to deserve the blows of fate. The idea that the state has a duty to provide for "innocent" victims reflect a new, and powerful norm: the norm of total justice. ${ }^{7}$ Jadi dalam hal ini ada tanggung jawab negara untuk selalu menyediakan kompensasi bagi warga negara yang dirugikan atau warga negara yang tidak bersalah yang menjadi korban dari tindakan pihak lain. Hal ini tercakup dalam konsep total justice.

Jika tidak tercapai kesepakatan, maka segala sesuatu yang dikemukakan, diungkapkan dan dipaparkan di forum mediasi memiliki konsekuensi etis, yaitu pihak yang jujur, polos, menyodorkan fakta yang sebenarnya agar tidak dimanipulasi oleh pihak-pihak yang tidak bertanggungjawab, maka keberadaan Pasal 13 merupakan keniscayaan. Dengan demikian segala pernyataan dan pengakuan yang muncul dalam proses mediasi tidak boleh digunakan sebagai alat bukti dalam proses persidangan perkara yang bersangkutan atau perkara lainnya. Begirtu pula, foto kopi dokumen dan notulen atau catatan mediator waijib dimusnahkan begitu pula Mediator sendiri tidak dapat menjadi saksi.dalam perkara tersebut.

Sesuai denga ketentuan Pasal 1 ayat (9) jo Pasal 4 PERMA No. 2 Tahun 2003, perkara yang menyangkut perlindungan konsumen termasuk Sengketa Publik, sehingga proses mediasinya harus terbuka untuk umum \{Pasal.
14 ayat (2)\}. Hal ini menegaskan bahwa halhal yang menyangkut kepentingan publik menuntut tingkat transparansi tertentu. Dalam kontek ini, kualitas transparansi adalah berupa sarana terbuka untuk umum. Dalam arti bahwa proses . mediasi yang berupaya mempertemukan antara kepentingan pihak pelaku usaha dan konsumen disyaratkan untuk dibuka dan terbuka bagi publik. Fasilitas hukum yang memberikan kewenangan untuk terbuka bagi umum, berarti publik berhak untuk melihat, mendengar dan mengetahui proses mediasi.

Dalam hubungannya dengan keputusan Majelis Badan Penyelesaian Sengketa Konsumen (BPSK). yang tidak diterima oleh para pihak dan mengajukan keberatan ke Pengadilan Negeri (Pasal 56 ayat (2) UUPK). Selanjutnya Pengadilan Negeri wajib mengeluarkan putusan atas keberatan tersebut (Pasal 58 ayat (1) UUPK), hàl ini terkait dengan produk yang harus dikeluarkan oleh. Pengadilan Negeri yang sesuai dengan ketentuan aturan hukum. Kalau produk yang harus dikeluarkan itu berupa Putusan, bukan keputusan, maka prosedur hukum yang harus ditempuh adalah gugatan perdata biasa sesuai dengan proses hukum acara yang berlaku.

Dewasa ini memang banyak perangkat hukum yang tidak applicable atau tidak efektif dalam praktik penerapannya, atau bahkan ada aturan hukum yang menjadi antik karena tidak

${ }^{7}$ Friedman, Lawrence M., Total Justice (Boston: Beacon Press, 1987), hlm. 67. Dalam hal ini Friedman juga memaparkan bahwa: The state, of course, punishes criminals at public expense, and criminals are in theory bound to make restitution to their victims. But you can't get blood from a stone, and most victims recover nothing from burglars, armend robbers, rapits, and thieves. They bear their losser themselves, often, to be sure, with the help of insurance. In 1965, however, Califomia began to offer compensation to victims of crime. 
pernah atau jarang sekali diterapkan, permasalahan ini merupakan bagian dari manajemen pembangunan hukum di negara kita yang masih dikelola dengan model supermarket. Termasuk di antaranya perangkat hukum yang tidak dapat diterapkan sesuai dengan tujuannya, adalah UU No. 8 Tahun 1999 dalam hal yang menyangkut hubungannya dengan Pengadilan negeri dan Penyidik.

Secara normatif PERMA No. 2 Tahun 2003 menentukan bahwa untuk menjadi seorang mediator di Pengadilan harus memiliki sertifikat mediator yaitu dokumen yang menyatakan bahwa seseorang telah mengikuti pelatihan atau pendidikan mediasi yang dikeluarkan oleh lembaga yang telah diakreditasi oleh Mahkamah Agung. Persyaratan ini ditujukan untuk mendukung latar belakang dikeluarlkannya PERMA ini dan agar penyelesaian perkara tidak justru menjadi rumit dan berlarut-larut jika mediatomya tidak memiliki komitmen terhadap asas umum penyelesaian perkara.

Secara konseptual dan yuridis, mediasi berbeda dengan arbitrase. Untuk itu, tidak dibenarkan proses mediasi dipaksakan menjadi arbitrase. Dalam masalah ini Bazerman dan Neale juga memaparkan bahwa: arbitrase differs from mediation in that the arbitrator determines the final out come. How arbitrator make that decision depends on the type of arbitration used. In positions of the conflicting parties, with the arbitrator usually selecting an agreement that falls between their final positions: Often, conventional arbitrators are accused of simply splitting the difference between the parties final offer. ${ }^{8}$ Jadi, dengan paparan Bazerman dan Neale, terlihat bahwa perbedaan antara arbitrase dan mediasi adalah adanya otoritas memutuskan hasil akhir yang dipunyai oleh arbitrator, sedangkan pada mediator otoritas kewenangan seperti itu tidak dipunyai.

\section{Dilema kekuatan hukum eksekutorial . putusan BPSK}

Untuk sahnya suatu putusan dituntut ada pemenuhan prosedur yang berlaku. Tanpa prosedur yang benar, suatu putusan dapat menjadi tidak sah menurut hukum. Keruntutan. kaidah prosedural mempengaruhi kualitas putusan dan kejemihan nalar hukum.

\section{Skema Prosedural}

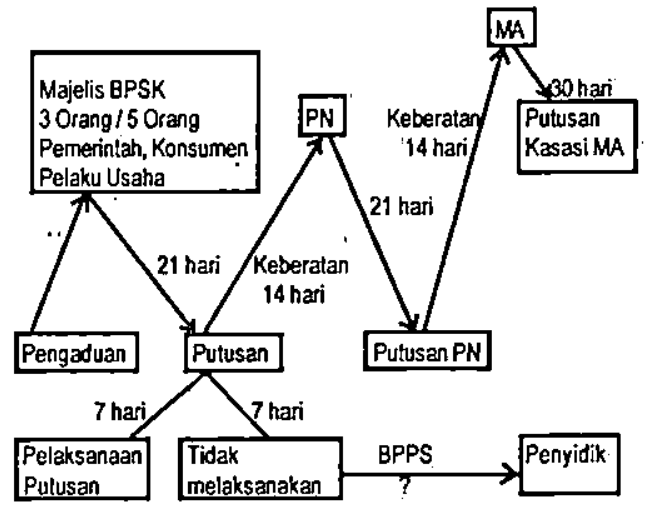

Dalam kacamata etika periu diperjelas jika Majelis BPSK itu terdiri dari 5 orang, karena secara yuridis lembaga tersebut terdiri dari elemen Pemerintah, Konsumen dan Pelaku Usaha. Kalau menjadi 5 orang maka akan ada

\footnotetext{
${ }^{8}$ Bazerman, MaxH. and Neale Margareth A., op.cit., him. 143.
} 
elemen yang tidak terwakili, sehingga untuk memperoleh legitimasi terhadap representativitas periu landasan yuridis. Begitu pula tentang elemen yang menjadi Ketua Majelis, menurut adanya landasan hukum.

Dalam perspektif etika, diperlukan adanya perangkat aturan dalam mekanisme pengambilan keputusan di BPSK, karena kemungkinan tidak terjadi suara bulat, harus diwadahi dan diatur secara jelas. Pengambilan keputusan dalam menilai fakta hukum yang menyangkut kepentingan publik atau masyarakat konsumen dapat menyangkut hati nurani dan eksistensi akal sehat (common sense). Keputusan yang menentukan hak-hak masyarakat konsumen, dapat menimbulkan the death of common sense-(matinya akal sehat), jika dasar kepentingan keputusan tidak memiliki nilai logis dan etis. Perbedaab pendapat dalam suatu proses pembentukan putusan adalah lazim, logis dan layak diakui atau diwadahi dalam institusi yang berparadigma demokratis.

Adanya dissenting opinion (perbedaan pendapat dengan anggota majelis yang lain) merupakan wadah yang mengakomodasi perbedaan pendapat di antara anggota majelis. Wadah ini di samping merefleksikan prinsip transparansi terhadap akuntabilitas kepada publik, juga dapat mengeliminasi adanya gesekan psikologis di antara anggota majelis, terutama anggota majelis yang. berpendapat dan hati nurani yang berbeda dengan yang mayoritas.

Pelaksanaan Pasal 58 yang menyatakan bahwa "Pengadilan Negeri wajib mengeluarkan putusan atas keberatan sebagaimana dimaksud dalam Pasal 56 ayat (2) dalam waktu paling lambat 21 dari sejak diterimanya keberatan". Sedangkan Pasal 56 ayat (2) menentukan bahwa "paara pihak dapat mengajukan keberatan (Keberatan atas putusan BPSK) kepada Pengadilan Negeri paling lambat 14 hari setelah menerima pemberitahuan, putusan". Dalam hal ini menurut kesesuaian dengan perangkat hukum yang lazim karena Putusan Pengadilan Negeri menurut adanya pemenuhan standar yang baku dan produk Pengadilan Negeri telah ditentukan pula secara yuridis.

Penyerahan kasus pihak yang tidak melaksanakan putusan BPSK kepada Penyidik, secara yuridis dituntut untuk memenuhi kualifikasi persyaratan bahwa ketentuan yang dilanggar itu menyangkut masalah pidana. Hal ini erupakan kewajiban yuridis bagi penyidik untuk tidak melibatkan diri dalam urusan perdata, karena dirinya tidak memiliki mandat hukum mengurus perkara perdata. Pada saat yang sama penyidik menghadapi gugatan dari Pengacara pihak yang merasa dirugikan, jika penyidik memaksakan diri berperan menjadi juru sita.

Standar baku penyusunan putusan memuat gugatan dalam perkara perdata atau dakwaan dalam perkara pidana yang intinya menunjukkan adanya posisi kasus dimana salah satu pihak merasa dirugikan oleh pihak lain. Dalam hal ini diperlukan adanya penjelasan hubungan hukum dan fakta yang relevan, yang mendukung gugatan atau dakwaan. Hal ini mengisyaratkan bahwa suatu putusan itu harus bermuatan nilai logis, sehingga dapat dipahami dan ditanggapi oleh publik yang berkepentingan atau concern terhadap keadilan hukum.

Setelah muncul adanya jawaban tergugat atau eksepsi dari terdakwa dalam tingkat judex favtie (bukan judex juris), diperlukan adanya paparan bukti atau saksi yang 
mendukung atau relevan.

Dari hal tersebut di atas, suatu putusan akan menggambarkan fakta hukum yang muncul di persidangan. Kemudian dari hubungan-hubungan fakta persidangan tersebut akan muncul hal tentang hukum-nya. Konstelasi ini menunjukkan betapa suatu putusan harus factual dan nalar hukum.

Berdasarkan hal-hal tersebut, lalu muncul pertimbangan-pertimbangan hukum yang mempertimbangkan hal-hal yang relevan secara yuridis dan beralasan menurut hukum. Setelah itu dalam kasus pidana bari dipertimbangkan hal-hal yang meringankan dan yang memberatkan. Atas dasar hal-hal tersebut di atas lalu ditentukan putusan yang berbunyi mengabulkan atau menolak gugatan, atau menyatakan gugatan itu tidak dapat diterima. Pertimbangan hukum suatu putusan, merupakan "legal reasoning" yang menuntut validitas fakta serta keakuratan norm-logis yang dipakai oleh hakim. Apakah yang dipakai memiliki nilai pembuktian dan memiliki hubungan kausal dengan pokok perkara.

Dalam kacamata sistem peradilan di Indonesia, pada dasamya putusan Majelis BPSK bersifat nonlitigasi, sehingga apabila ada pihak yang keberatan atau putusan BPSK tersebut, mereka dapat mengajukan keberatan kepada Pengadilan Negeri. Dalam arti pula, putusan BPSK ini tidak memiliki kekuatan eksekutorial. Ketentuan Pasal 58 UU No. 8 Tahun 1999 yang mewajibkan Pengadilan Negeri disyaratkan untuk memproses penyelesaian suatu perkara dengan melalui acara gugatan perdata biasa. Hal ini menunjukkan bahwa posisi proses hukum dan putusan BPSK itu pada dasamya non-yudisial. Dalam arti pula, putusan BPSK itu merupakan gerbong lain dari rangkaian gerbong mekanisme sistem pengadilan, jadi berada di luar mekanisme pengadilan umum.

Setelah keluamya Putusan BPSK, kecuali para pihak bersepakat dan mematuhi putusan tersebut, pihak yang berperkara atas putusan itu alternatifnya adalah mengajukan keberatan ke Pengadilan Negeri dan jika masih ada yang keberatan dapat mengajukan kasasi ke Mahkamah Agung. Hal ini mengisyaratkan bahwa Putusan BPSK dituntut untuk memenuhi tuntutan fungsi keberadaannya sebagai lembaga penyelesaian sengketa nonyudisial.

Dalam kerangka upaya membangun integritas institusi BPSK diperlukan standar baku dan kualifikasi personal dari para Ketua Majelis BPSK serta KODE ETIK diperlakukan kepadanya. Pada saat yang sama juga harus dipenuhi adanya standar formulasi putusan BPSK, sehingga dimungkinkan adanya kontrol dan evaluasi (semacam eksaminasi) atas putusan' BPSK sehingga dapat dipertanggungjawabkan integritas dan norma logisnya di masyarakat. Penyelarasan ketentuan UU No. 8 Tahun 1999 dengan UU lain harus dilakukan. Antara lain, limitasi waktu dalam proses pengeluaran putusan di Pengadilan Negeri (21 hari) dan di Mahkamah Agung (30 hari) dengan kondisi yang ada, menjadi tidak realistis. Begitu pula dengan UU lainnya, yaitu dengan UU No. 8 Tahun 1981 tentang hukum Acara Pidana agar pelaksanaan putusan BPSK tidak berbenturan dengan aturah hukum yang lain sehingga putusan BPSK menjadi mandul dan tidak dapat dilaksanakan.

\section{Prospek dan Rekomendasi}

Keberadaan Undang-undang No. 8 
Tahun 1999 tentang pertindungan konsumen pada dasarnya merupakan upaya untuk memberikan perlindungan bagi masyarakat konsumen. Sebagaimana juga dilakukan oleh berbagai negara lain di dunia. Di Amerika Serikat (AS) misalnya ada aturan yang dikenal dengan The Customer Product Safety Act $(\mathrm{CPSA})^{9}$ dan The Federal Hazardous Substances Act (FHSA), merupakan undangundang yang diberlakukan tahun 1970 oleh the Food and Drug Administrastion (FDA) yang implementasinya dilakukan oleh suatu komisi. Peraturan ini memuat larangan terhadap apa yang disebut "Law and Dart". Atas dasar larangan tersebut penggunaan produk yang ditujukan untuk orang dewasa, harus ada label: 1) are labeled to wam against use by children, 2) include instruction for save use, and 3) are not sold by toy atores or by store departemens dealing predominantly in toys or other children's articles. Dengan demikian, pencantuman larangan digunakan oleh anakanak, petunjuk penggunaan yang aman, dan tidak dijual bercampuran dengari miainan anak-anak, merupakan kewajiban yuridis bagi penjualan produk di Amerika Serikat.

Dalam proses industrialisasi, tersedianya perangkat hukum yang menjamin kepastian dan perlindungan usaha merupakan suatu keniscayaan. Dunia perusahaan baik barang maupun jasa, tidak lepas dari masalah kompetisi, bahkan kompetisi selalu diperlukan karena merupakan bagian dari dinamika. Kompetisi yang bermanfaat dan efisien adalah kompetisi yang sehat. Keberadaan aturan hukum diperlukan pula dalam upaya menciptakan iklim usaha dan praktek kompetisi yang benar, Negara AS merupakan negara yang bergerumul lama dengan permasalahan undang-undang antimonopoli yaitu sejak antitrust law yang dikenal dengan the Sherman Act tahun 1890.

Selain telah mengalami beberapa kali amandemen antitrus law tersebut dalam perkembangannya kemudian menyangkut perdagangan internasional, seperti dielaborasi oleh Ralph $\mathrm{H}$. Folson ${ }^{10}$ et.al, some limits on the extraterritorial reach of the Sherman Act are created by the act state doctrine and the Foreign Sovereign immunities Act. Perangkat hukum yang mengatur tentang larangan monopoli dan berkehendak menciptakan iklim kompetisi yang sehat dalam dunia usaha, merupakan kebijakan dalam ekonomi, khususnya di bidang perdagangan. Kekuatan ekonomi dunia bisnis dering berselingkuh melakukan hubungan kolutif dengan kekuasaan politik para pemimpin pemerintahan. Untuk itu, keberadaan aturan hukum yang berspinit kerakyatan diperlukan untuk menciptakan check and balances atas kekuatan monopoli ini berkaitan dengan

${ }^{8}$ Hàrrison, Jeffrey L, et al, Regulation and Deregulation, Cases and Material (Minnesota: West Publishing Co., st, Paul, 1977), hlm. 295.

${ }^{10}$ Folson, Ralph H., et.al. International Business Transaction(Minnesota: West Publishing Co., St. Paul, 1988), hlm. 162. Dalam hal ini Ralph H. Folson et.al. juga memaparkan bahwa: territoriality is a matter of balance. The executive, Legislative and Judicial branches of govemment in the United States have reached out extraternitoriality in the law admirally, antutrust, crime, labour, securities regulation, taxation, torts, trademarks and wildife management. 
keselamatan dan kesejahteraan konsumen (consumer welfare). Seperti halnya yang dikemukakan oleh Thomas $M$. Jorde dan David $j$. Teece ${ }^{11}$ yang mengemukakan bahwa: affort to link antitrust to consumer welfare may fall wide of the mark whenever the focus in on present consumer welfare, which is the common focus of microeconomic theory. Keterkaitan antara larangan monopoli dengan keamanan konsumen merupakan bagian dari jangkauan kajian ilmu ekonomi, karena kedua hal tersebut merupakan sesuatu yang harus ada dalam proses penegakan etika bisnis.

Tulisan ini memberikan rekomendasi jika ada upaya amandemen dan perombakan terhadap UU No. 8 Tahun 1998 tentang Perlindungan Konsumen, karena terdapat beberapa pasal yang tidak applicable karena tidak sesuai dengan ketentuan aturan undangundang yang lain. Akibat dari adanya cacad substansial dalam beberapa pasal tersebut, maka tujuan untuk melindungi konsumen tidak tercapai. Bahkan yang tujuannya untuk mengurangi beban kuantitas perkara dalam pengadilan umum, lalu bergaya balik menjadi menambah beban bagi pengadilan. Begitu pula kualifikasi personal orang yang duduk di BPSK perlu diperjelas dan kode etik personal perlu ditegakkan. Apalagi untuk masa mendatang masyarakatkonsumen akan semakin meningkat tuntutan kualitas perlindungan. Seperti yang dipaparkan oleh Michael J. Wolf bahwa: consumen reports online, the web site from consumer reports magazine, has signed on more than 180.000 subscribers, making it one of the most successful for-pay ites on the Intemet. In addition on the standard Consumer Reports product rating, subscribers get access to massage boards that allow them to consult experts and discuss information on such topics as cars, cell phone, car leasing, and financing college. ${ }^{12}$ Dengan meningkatnya sarana advokasi dan pola tuntutan konsumen, maka konsekuensi logisnya fasilitas aturan hukum juga harus dapat mewadahi kebutuhan perkembangan sosial dan teknologi.

Regulasi tentang perlindungan konsumen, pada dasamya merupakan bagian dari hukum yang memberikan kesejahteraan bagi masyarakat. Secara ekonomi, masyarakat konsumen memiliki kedaulatan hak yang harus dilindungi. Bagaimana merespon adanya gejala memperdaya konsumen ini Robert Kuttner mengemukakan bahwa the challenge was to make sure mar-

\footnotetext{
"Jorde, Thomas M and Teece, David J., Antiitrust, Innovation, and Competitiveness (Oxford: University Press, 1992), him. 4.

${ }_{12}$ Wolf, Michael J., The Entertainment Economy (New York: Random House, 1999), hlm. 211. Dalam hal ini Wolf juga memaparkan bahwa: another subscribers model, equally well thought out in my view, is ESPN site. Rather than simply repurposing its felevision content, ESPN enhances and broadened the content offering. For the score-obsessed sports junkie, stats and scores are available on demand. No more having to tune in to all-news radio at fifteen minutes affer the hour, no more phone calls to a 900 number droning on through an endless list of scores that the consumermight have no interest in at all. ESPN.com, by virtue of its interactivity, allows the consumer to get the information desired in the shortest possible time. On-line discussion areas on this same site further foster the building of a community around the ESPN brand. Much as the Wall Street Joumal Interactive Edition did, ESPN also created a subscription tier for those who wanted even more.
} 
kets did not become rigged by monopolist or used deceptivelly against consumeers. For these reformers, the favourite remedies were. antitrust, disclusure, labeling, and only occasionally the deleberate counter monding of the price mechanisme..$^{13}$ Jadi dalam upaya melawan para pelaku usaha agar tidak seenanya memperdaya konsumen, jalan yang harus ditempuh antara lain adalah regulasi antimonopoly, keterbukaan dan pemberian label. Upaya ini termasuk upaya mediasi bagi tuntutan konsumen telah difasiliasi aturan hukum di Indonesia, hanya saja perangkat hukum itu harus disempumakan. Perubahan dan pembentukan hukum memang merupakan bagian dari reformasi di Indonesia.

\section{Daftar Pustaka}

Bazerman, Max H. and Neale, Margareth A., Negotiating Rasionality, New York:The Free Press, 1993.

Beard, Charles A., The Supreme Court And The Constitution, New Jersey: Prentice-Hall, Inc., Englewood Cliffs, 1962.

Black, Henry Campbell, Black's Law Dictionary, St. Paul: West Publishing Co., 1990.

Coubrey, Hilaire Mc. \& White, Nigel D., Textbook on JURISPRUDENCE, New York: Oxford University Press, 1999.

Feldman, Stephen M., American Legal Thought from Premodernism to postmodemism, New York: Oxford University Press, 2000.
Friedman, Lawrence M., Total Justice, Boston: Beacon Press, 1987

Friedman, Lawrence M., American Law an Introduction, Hukum Amerika Sebuah Pengantar, (terjemahan), Jakarta: PT. Tatanusa, 1998.

Folson, Ralph H. et. al., Intemational Business Transactions, Minnesota: West Publishing Co., St. Paul, 1988.

Harrison, Jeffrey L., et al., Reguilation and Deregulation, Cases and Material, Minnesota: West Publishing Co., St. Paul., 1997.

Howard, Philip K., The Death of Common Sense, New York: Warner Books Inc., 1996.

Jacob, Herbert (et.al) Court Law \& Politics in Coparative, New Haven: Yale University Press, 1996.

Jorde, Thomas and Teech, David J., Antitrust, Innovation, and Competitiveness, New York: Oxford University Press, 1992.

Kelly, Kevin, New Rules for The New Economy, New York: Penguin Group, 1998.

Kuttner, Robert, Everything for Sale, New York: Alfred A Knopp, 1997.

Mc. Kenzie, Richard, Trust on Trial, Cambridge: Perseus Publishing, 2000.

Morgan Robin, The Anatomy of Freedom, New York: WW. Norton \& Company, 1982.

Palast, Greg, The Best Democracy Money Can Buy, England: A Plume Book, 2003.

${ }^{13}$ Kuttner, Robert, Everything for Sale (New York: Affred A. Knopp, 1997), hlm. 233. 
Schuck, Peter H:, The Limit Of Law, Essays on Democratic Governance, Colorado:

Westview Press, 2000.
Theory of Lawyers' Ethics, Massachusetts: Harvard University Press, Cambridge, 1998.

Simon, William H., The Practice of Justice, $A$ Wolf, Michael J., Entertainment Ecinomy, New York: Random House, 1999.

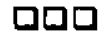

